\title{
SURVEY OF BREAST CANCER IN WASIT PROVINCE , IRAQ
}

\author{
Abduladheem Turki Jalil ${ }^{1}$, Saja Hussain Dilfi ${ }^{2}$, Aleksandr Karevskiy ${ }^{1}$ \\ Corresponding author: abedalazeem799@gmail.com \\ 1 Faculty of Biology and Ecology, Yanka kupala state university of Grodno, Belarus \\ 2 Department of histopathology, Faculty of Science, Wasit university, Iraq
}

\begin{abstract}
Introduction: Cancer is one of the most common causes of death among females. In our research, cancer data were collected in Wasit Governorate for patients who were referred to Al-Zahra Educational Hospital for the period From February 2010 to February 2019. The results showed that breast cancer is the most common type of cancer in Wasit governorate and by percentage (35.4\%) with 341 out of 966 cases of cancer. Methods: Data were collected from data base between the year (2010 to 2019), with the highest rate of cases in 2013, which is around 139 cases, of these cases around 71 were breast cancer (51.07\% recurrence). Surprisingly the lowest cases were recorded in a year after (2014) with total cancer cases of 65 from them 21 cases of breast cancer only. Results: About the relationship between breast cancer and gender, breast cancer recorded $95.60 \%$ of the cases in females, while percentage of men cases only $4.39 \%$. Conclusion: The higher percentage of the cases were around $40-$ 49 years old , 92 cases (27\%) , 80 cases (23.5\%) were in the age group (50-59 years) and 65 cases (19\%) were in the age group (30-39 years) and 51 cases (15\%) were in the age group (60-69 years) ). The lowest percentage of breast cancer was in the 10-19 age group, with only two cases $(0.5 \%)$.
\end{abstract}

Keywords: Breast cancer, Women, Wasit, Age, Gender 


\section{Introduction}

Breast cancer is one of the most common cancers among women, and one of the leading cause of death among female. There are several factors that lead to breast cancer: these factors are age, early menstruation, late pregnancy, obesity, oral contraceptives, hormone replacement therapy, diet, family history, decreased breastfeeding and history of pre-existing benign breast cancer. (Bray et al., 2012) (Brinton et al.,2018). Breast cancer is the most commonly diagnosed cancer among women worldwide, accounting for 25\% (Over 1.5 million) women with cancer cases at all ages and a greater percentage among young women (Torre et al.,2017).In America, it is estimated that $30 \%$ of all new cancer cases $(252,710)$ among women are breast cancer (Siegel, et.al .2016). In Iraq, Breast cancer is the most common type of cancer among females. According to the Children's Cancer Research Institute (CCRI), it ranks first in female cancer, and accounting for about a third of all cancers registered according to the latest Iraqi Cancer Register (IARC, 2013)Breast cancer is a complex and multifactorial disease resulting in abnormal cell growth that leads to malignant tumour formation. It is the most common female cancer, affecting one in eight women during their lifetime. Approximately $10 \%$ of all breast cancers are hereditary, most commonly caused by genetic variations transmitted in an autosomal dominant manner (Howlader et al ., 2013 ) .Simply being a woman is the main risk factor for developing breast cancer. Men can develop breast cancer, but this disease is about 100 times more common among women than men (Feng et al.,2018). The first physical symptoms of breast cancer include swelling of the breast, skin scrapping, pain in the nipple, secretions, redness, or skin scrapping of the nipple or breast (Mangesi \& Zakarija-Grkovic, 2016). The aim of the study is to find out the most common cancer and its relationship to age and Gender.

\section{Methods}

This study done by collection of cancer data for the years 2010 to February 2019 for the patients from Histopathology Unit in Al-Azahraa Educational Hospital in Wasit Governorate. Who were diagnosed and confirmed having cancer by histopathological study Data were collected from data base between the year (2010 to 2019), with the highest rate of cases in 2013, which is around 139 cases, of these cases around 71 were breast cancer $(51.07 \%$ recurrence).Surprisingly, the lowest cases were recorded in a year after (2014) with total cancer cases of 65 from them 21 cases of breast cancer only. The collected data for each patient include history of infection, age, gender, residential area. These statistics included all types of cancers and the study focused on data of breast cancer patients for the period mentioned. Data were distributed according to years, gender and age.

\section{Results}

The results of this study, as shown in Table 1, showed that breast cancer recorded the highest percentage of cancers among the other cancers $(35.4 \%)$.

\section{Table 1: Breast cancer prevalence rate}

\begin{tabular}{|c|c|c|c|}
\hline $\begin{array}{c}\text { Type } \\
\text { of } \\
\text { Cancer }\end{array}$ & $\begin{array}{c}\text { frequency } \\
\text { of total } \\
\text { cancer } \\
\text { cases }\end{array}$ & $\begin{array}{c}\text { Frequency } \\
\text { Of cancer } \\
\text { cases }\end{array}$ & $\begin{array}{c}\text { Percentage } \\
\%\end{array}$ \\
\hline $\begin{array}{l}\text { Breast } \\
\text { cancer }\end{array}$ & 966 & 341 & $35.4 \%$ \\
\hline
\end{tabular}


Table 2 shows the distribution of breast cancer during the past 10 years, with the highest rate of cases in 2013.

Table 2:Distribution of breast cancer according to years

\begin{tabular}{|c|c|c|c|}
\hline Years & $\begin{array}{l}\text { No. of } \\
\text { cancer } \\
\text { cases }\end{array}$ & $\begin{array}{l}\text { No. of } \\
\text { breast } \\
\text { cancer } \\
\text { cases }\end{array}$ & $\begin{array}{c}\text { Percentage } \\
\%\end{array}$ \\
\hline $\begin{array}{l}2010- \\
2011\end{array}$ & 71 & 27 & 38.02 \\
\hline $\begin{array}{l}2011- \\
2012\end{array}$ & 104 & 45 & 43.26 \\
\hline $\begin{array}{l}2012- \\
2013\end{array}$ & 84 & 29 & 34.52 \\
\hline $\begin{array}{c}2013- \\
2014 \\
\end{array}$ & 139 & 71 & 51.07 \\
\hline $\begin{array}{l}2014- \\
2015\end{array}$ & 65 & 21 & 32.30 \\
\hline $\begin{array}{c}2015- \\
2016 \\
\end{array}$ & 108 & 32 & 29.62 \\
\hline $\begin{array}{l}2016- \\
2017\end{array}$ & 161 & 38 & 23.60 \\
\hline $\begin{array}{c}2017- \\
2018\end{array}$ & 141 & 41 & 29.07 \\
\hline $\begin{array}{c}2018- \\
2019\end{array}$ & 87 & 33 & 37.93 \\
\hline & 6 & 4 & 6.66 \\
\hline Total & 966 & 341 & $35.4 \%$ \\
\hline
\end{tabular}

Prevalence of Breast cancer according to Gender

The results showed that breast cancer recorded $95.60 \%$ of the cases in females, while men had $4.39 \%$ of the disease.
Table 3: Distribution of breast cancer according to gender

\begin{tabular}{|c|c|c|c|c|c|}
\hline Years & $\begin{array}{c}\text { No. of } \\
\text { breast } \\
\text { cancer }\end{array}$ & Male & $\begin{array}{c}\text { Percent } \\
\%\end{array}$ & Female & $\begin{array}{c}\text { Percent } \\
\%\end{array}$ \\
\hline $2010-2011$ & 27 & 0 & 0 & 27 & 100 \\
\hline $2011-2012$ & 45 & 4 & 8.88 & 41 & 91.11 \\
\hline $2012-2013$ & 29 & 0 & 0 & 29 & 100 \\
\hline $2013-2014$ & 71 & 7 & 9.85 & 64 & 90.14 \\
\hline $2014-2015$ & 21 & 0 & 0 & 21 & 100 \\
\hline $2015-2016$ & 32 & 1 & 3.12 & 31 & 96.87 \\
\hline $2016-2017$ & 38 & 2 & 5.26 & 36 & 94.73 \\
\hline $2017-2018$ & 41 & 1 & 2.43 & 40 & 97.56 \\
\hline $2018-2019$ & 33 & 0 & 0 & 33 & 100 \\
\hline $2019(2 m o n t h s)$ & 4 & 0 & 0 & 4 & 100 \\
\hline Total & 341 & 15 & $\mathbf{4 . 3 9}$ & 326 & 95.60 \\
\hline
\end{tabular}

Prevalence of Breast cancer according to Age

Figure 1 showing the relationship between breast cancer and age in this study revealed the distribution of patients in the age groups.

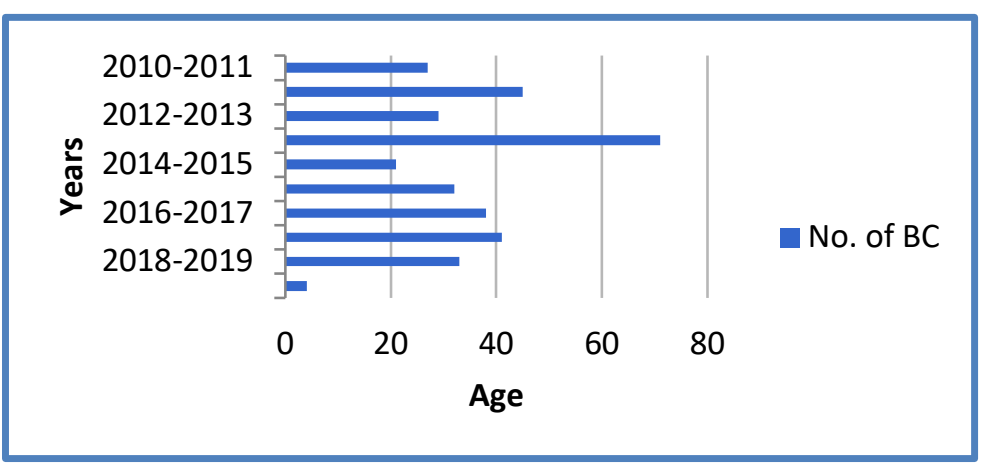

Figure 1: Distribution of breast cancer according to gender 


\section{Discussion}

\section{Overall Prevalence of Breast cancer in last years}

The total number of cancer cases during this period was 966 of cancers, and breast cancer recorded 341 cases and thus ranked first among the other types of cancers diagnosed in Wasit Governorate. The rate of deaths caused by the disease is $16 \%$ in all countries of the world, including Iraq, where people suffers from the disease and other types of cancer most probably due to wars and environmental pollution in the large provinces, especially the south, where people exposed to different radioactive materials and weapons, as well as carcinogenic chemicals in some industries (Fathi et al.,2013).

\section{Prevalence of Breast cancer according to years}

with 139 cases of cancer, of which 71 cases were breast cancer with a recurrence rate $51.07 \%$. Followed by 2011 with 104 cases of cancer, including 45 cases of breast cancer, a recurrence rate of $43.26 \%$. While the lowest incidence rate was recorded in 2016 and 2019 with recurrence rate of $23.60 \%, 6.66 \%$ respectively.

\section{Prevalence of Breast cancer according to Gender}

This means that females are more likely to have Breast cancer, for several reasons including: pregnancy and exposure to hormone estrogen, which increases the incidence of the disease. There is also genetics factors, women who have relatives of the first degree (mother - sister - daughter) who have the disease are Women are $5 \%$ to $10 \%$ more likely to develop the disease than others . There is a chemical factors such as medicines and that women deal with such as Contraception treatments, alternative hormones taken by women after the age of menopause and hormones that cause obesity Unhealthy diet, such as consuming foods high in fat. In developed countries, almost $99 \%$ of breast cancer cases are diagnosed in women; While men account for $5-15 \%$ of breast cancer cases in a few African countries that have the highest incidence of breast cancer in men. Breast cancer is the highest cancer in women in Iraq, with total number of cases in 2018 (according to World Health Organization figures) about $5141(20.3 \%)$ of all cancers, followed by lung cancer. While lung cancer is the highest in men, 1573 , and $13.9 \%$ of all cancers in men, followed by bladder cancer. The World Health Organization (WHO) forecast for the past five years of breast cancer is 1,3006. For all 2018 men and women in Iraq, 25320 cases have a total of 54,809 deaths and a total of 14524 deaths in 2018.The males may develop breast cancer but with a much lower rate, one case in male compared to 100 cases in female this is because the low level of estrogen in male compared to female. The strongest risk factors for men are the diagnosis with klinefelter syndrome at birth, where the child is born with two $\mathrm{X}$ chromosome rather than one $(X X Y)$ rather than $(X Y)$, although men with klinefelter syndrome may develop breast hypertrophy, while breast enlargement is not associated with Breast cancer in men. As with women, the risk factors for breast cancer in men increase with changes in the BRCA2 gene, alcoholism, chronic liver disease, and obesity may increase the risk of breast cancer. 


\section{Prevalence of Breast cancer according to Age}

The most of the patients 92 cases $(27 \%)$ in the age group ( $40-49$ years), 80 cases $(23.5 \%$ ), in the age group (50-59 years) and 65 cases (19\%) were in the age group (30-39 years) and 51 cases $(15 \%)$ were in the age group (60-69 years). Were in the age group (10-19 years) where only two cases $(0.5 \%)$. The other factor that has a role in disease is the age factor. It is known that breast cancer affects women after the age of 50 , but recently in Iraq and other countries the disease begin to appears in the young age between the age of (30-40) years and also few cases occur in age 20 years in this ages frequent deliveries and exercise allow the body of women to get rid of excess estrogen, but it is not related to estrogen only, but to the rest of the factors of this precaution and regular self-examination and early diagnosis ensures prevention and treatment dramatically when the signs of disease. The results of this study showed that the highest rate of cases was at the age (4049 years) and (50-59 years) and these results are consistent with the findings of Alwan (2010), which was a study conducted in Baghdad, where the results of this study that the highest rate of cases were in the age group (40-49 years) and (50-59 years), which recorded $(31.9 \%)$ and $(26.4 \%)$, respectively. Another study finds similar result where the peak in this age group was recorded by the Iraqi Cancer Register (ICR, 2005). Another Iraqi study conducted by (Mayada, 2013) showed that about $68.2 \%$ of the patients in the study were under the age of 50 years. The results of this study are also consistent with an Egyptian study conducted by Omar et al., (2003), which showed that the peak incidence of breast cancer was in the age group (40-59 years). These results coincide with a Saudi study by Elkhum (2007), noting that the average age of cases were 45 years. Also our result agrees with Rambau et al., (2011) who reports that patients with breast cancer mean age at diagnosis was 49 years. The results of this study agree with a study which is done by Nyante et al., (2013) who find relationship between breast cancer type and age at first birth, and also agree with a study which is done by Ozmen et al., (2009) observes that the $(\geq 30)$ years age at first birth is associates with increased breast cancer risk.

\section{Conclusion}

We concluded from this study that breast cancer is the most common cancer in Wasit province, the highest rate of cases was in 2013, Female are more likely to develop breast cancer than male and the most vulnerable age groups are between 40-60 years old.

\section{References}

- Alwan, N.A. (2010). Breast cancer: demographic characteristics and clinicopathological presentation of patients in Iraq. EM HJ., 16: 1159-1164.

- Bray , F., Ren, J.S., Masuyer, E. , Ferlay, J. (2012). Global estimates of cancer prevalence for 27 sites in the adult population in 2008. Int. J. Cancer,132: 1133-1145.

- Brinton, L. A., Brogan, D. R., Coates, R. J., Swanson, C. A., Potischman, N., \& Stanford, J. L. (2018). Breast cancer risk among women under 55 years of age by joint effects of usage of oral contraceptives and hormone replacement therapy. Menopause, 25(11), 1195-1200.

- Elkum , N., Dermime, S., Ajarim, D., AlZahrani, A., Alsayed, A., Tulbah, A. ( 2007 ). Being 40 or younger is an independent risk factor for relapse in operable breast cancer patients: The Saudi Arabia experience BMC Cancer.7:222. 
- Fathi, R. A., Matti, L. Y., Al-Salih, H. S., \& Godbold, D. (2013). Environmental pollution by depleted uranium in Iraq with special reference to Mosul and possible effects on cancer and birth defect rates. Medicine, conflict and survival, 29(1), 7-25.

- $\quad$ Feng, Y., Spezia, M., Huang, S., Yuan, C., Zeng, Z., Zhang, L., \& Liu, B. (2018). Breast cancer development and progression: Risk factors, cancer stem cells, signaling pathways, genomics, and molecular pathogenesis. Genes \& diseases, 5(2), 77106.

- Howlader, N ., Noone, A. M. , Krapcho, M., Garshell, J. , Miller, D. , et al. (eds.) (2013). SEER Cancer Statistics Review, 19752010. Bethesda, MD: National Cancer Institute.

- International Agency for Research on Cancer (IARC), (2013). Latest world cancer statistics Global cancer burden rises to 14.1 million new cases in 2012: Marked increase in breast cancers must be addressed. press release $\mathrm{N}^{\circ} 223 \mathrm{pp} 1-2$

- International Agency for Research on Cancer (IARC), (2013). Latest world cancer statistics Global cancer burden rises to 14.1 million new cases in 2012: Marked increase in breast cancers must be addressed. press release $\mathrm{N}^{\circ} 223 \mathrm{pp} 1-2$.

- Iraqi Cancer Registry (2005). Results of the Iraqi Cancer Registry.Baghdad, Iraqi Cancer Registry Center, Ministry of Health.

- Mangesi, L., \& Zakarija-Grkovic, I. (2016). Treatments for breast engorgement during lactation. Cochrane Database of Systematic Reviews, (6).

- Mayada , I. Y.( 2013). Esterogen and Progesterone Receptors (ER and PR) status of Breast Cancer Cases in Kurdistan and Their Correlation with Pathologic Prognostic Variables. Medical Journal of Babylon;10(1):75-84.

- Nyante, S. J., Dallal, C.M., Gierach, G.L., Park, Y., Hollenbeck, A.R., Brinton, L.A. (2013). Risk factors for specific histopathological types of postmenopausal breast cancer in the NIH-AARP Diet and Health Study.American journal of epidemiology, 178:359-71.

- Omar, S., Khaled, H., Gaafar ,R., Zekry, AR., Eissa, S., el-Khatib, O., et al. (2003) .Breast cancer in Egypt: a review of disease presentation and detection strategies. Eastern Mediterranean Health Journal May; 9(3):448-63.

- Ozmen, V., Ozcinar, B., Karanlik ,H.(2009). Breast Cancer Risk Factors in Turkish Women - a University Hospital Based
Nested Case Control Study. World Journal of Surgical Oncology: 7-37.

- Rambau, P. F., Chalya, P. L., Manyama, M. M. and Kahima, J. K. (2011).Pathological features of breast cancer seen in Northwestern Tanzania: a nine years retrospective study. BMC Research Notes 4, 214.

- Siegel, R. L., Miller, K. D., \& Jemal, A. (2016). Cancer statistics, 2016. CA: a cancer journal for clinicians, 66(1), 7-30.

- Torre, L.A., Islami, F., Siegel, R.L.,Ward, E.M., Jemal, A.(2017).Global cancer in women: burden and trends. Cancer Epidemiol Biomarkers Prev.;26(4):444457.

- WHO (2013). Cancer control: knowledge into action: WHO guide for effective programmes: early detection. 